\title{
Editorial
}

\section{Cardiomyopathies - the message for the 1980s Part II}

Further articles based on papers given at the International Symposium in Lisbon in October 1984 are presented in this second part of the publication. The papers represent a wide spectrum covering many aspects of cardiomyopathies and reflecting the views and conclusions of experts.

The significance of left ventricular gradients in hypertrophic cardiomyopathy has been a source of controversy for the past 20 years. Michael Criley from Torrance, California, and Douglas Wigle from Toronto, Canada, have long been protagonists in the debate over the significance of left ventricular gradients, and their views are well represented here.

John F. Goodwin

William J. McKenna Roando Alvares 